\title{
Sensitivity of Leaf Spot Causing Pathogen of Bitter Gourd (Cercospora citrullina Cooke) To Different Fungicides
}

\author{
Dindo King M. Donayre ${ }^{1}$ and Lucille T. Minguez ${ }^{2}$
}

${ }^{1}$ Research Division, Philippine Rice Research Institute-Negros Station, Cansilayan, Murcia, Negros Occidental, Philippines; ${ }^{2}$ Northern Mindanao Integrated Agricultural Research Center, Dalwangan, Malaybalay City, Bukidnon, Philippines

\begin{abstract}
Cercospora leaf spot disease caused by Cercospora citrullina Cooke is one of the most important diseases of bitter gourd. Effective fungicide against the causal pathogen has not been reported. This study was conducted at the Plant Pathology Laboratory of the Crop Protection Cluster, College of Agriculture, University of the Philippines Los Baños, College, Laguna to (a) determine the sensitivity of $C$. citrullina Cooke to different fungicides, and (b) determine the most effective fungicide against C. citrullina. Four fungicides, namely, benomyl $\left(0.63 \mathrm{~g}\right.$ a.i. $\left.\mathrm{L}^{-1}\right)$, chlorothalonil (1.41 g a.i. $\left.\mathrm{L}^{-1}\right)$, copper oxychloride $\left(0.63 \mathrm{~g}\right.$ a.i. $\left.\mathrm{L}^{-1}\right)$ and mancozeb (3 g a.i. $\left.\mathrm{L}^{-1}\right)$ were tested against the pathogen. Under laboratory condition, all conidia of $C$. citrullina did not germinate when treated with the test fungicides. Under screenhouse condition, the fungicides also effectively suppressed the development of the disease owing to low number and non-increasing of lesions in the leaves of bitter gourd. All test fungicides were very effective against leaf spot disease causing pathogen of bitter gourd.
\end{abstract}

Keywords: Cercospora citrullina, Momordica charantia, leaf spot, benomyl, chlorothalonil, copper oxychloride, mancozeb

Correspondence: D. K. M. Donayre Address: Research Division, Philippine Rice Research InstituteNegros Station, Cansilayan, Murcia, Negros Occidental, Philippines E-mail: dindoking@yahoo.com

DOI: 10.32945/atr3616.2014 


\section{INTRODUCTION}

Bitter gourd (Momordica charantia L.), locally known as ampalaya in the Philippines, is an annual climbing herbaceous vine that belongs to the Cucurbitaceae Family. It has tender and simple tendrils that can reach more than $3 \mathrm{~m}$ from the ground; hence, require vertical and overhead trellis for support. It is extensively cultivated for its edible fruits and young shoots which are sold in markets almost in all seasons throughout the Philippines. Bitter gourd is rich in calcium, iron, vitamin B and carbohydrates (Zamora, 1993). It is also considered a good source of medicine for curing diabetes (PhilRice, 2007). Whole young bitter gourd plants are now being powdered and processed into capsules and sold as an antidiabetic drug. In diversified farming such as the Palayamanan System ${ }^{\circledR}$, bitter gourd is one of the most recommended vegetables not only due to its nutritious content but also for its market demand (PhilRice, 2007). The total production of bitter gourd throughout the country in 2007 was 83,144 metric tons (BAS, 2008). Currently, production and demand for bitter gourd are still increasing. However, its maximum production is sometimes not always met due to occurrence of diseases.

Cercospora leaf spot caused by Cercospora citrullina Cooke is one of the most important diseases in most bitter gourd production in the Philippines (Tangonan 1999; Begum et al. 2012). The pathogen also infects other related cucurbits such as watermelon, muskmelon, cucumber, squash, pumpkin, gourd, and chayote (Tangonan 1999; Begum et al. 2012). In bitter gourd, symptomatology of the disease starts as small, circular, whitish or dark brown leaf spots but when favorable conditions occur, these spots enlarge and coalesce forming irregular lesions with whitish center and dark brown margins (Chupp 1953). In the advanced stage, the fructifications of the fungus (conidia and condiophores) develop at the center of the spots. Heavy infection of the disease may cause significant defoliation and death of entire vines (EWSC, 2009).

Fungicides are chemicals used to control fungal diseases in plants and often classified either protectant or systemic. Though they are not the only way to protect plants from pathogens causing diseases, they are best recognized by the general public due to convenience in terms of usage and reliability on the effects of control (Maloy 1993). The use of fungicides against Cercospora leaf spot of bitter gourd, on the other hand, has not been reported except for benomyl: a systemic fungicide (Anonymous, 2009). There are many available fungicides in the market but none of these had been formally evaluated against Cercospora leaf spot disease of bitter 
gourd. Hence, this study aimed to determine the sensitivity of $C$. citrullina to different fungicides, and (b) determine the most effective fungicide against $C$. citrullina.

\section{MATERIALS AND METHODS}

\section{Preparation of Test Plants}

One hundred fifty healthy seeds of bitter gourd (var. Galaxy of EastWest Seed Co.) were sown in seed boxes $(0.5 \mathrm{~m} \times 0.5 \mathrm{~m})$ containing sterilized soil at a depth of $2 \mathrm{~cm}$. Newly sown seeds were sprinkled with water to further enhance emergence. After two weeks, each growing seedling was transplanted to 4-in diameter clay pot previously filled with sterilized soil and allowed to grow under screenhouse conditions. Recommended rates of fertilizer and amount of water were provided when necessity arouse.

\section{Isolation of the Pathogen}

Infected leaves of bitter gourd were collected at the vegetable area of the Agronomy and Soil Science Cluster and brought into the Plant Pathology Laboratory of the Crop Protection Cluster, College of Agriculture, University of the Philippines Los Baños, College, Laguna for microscopic examination, isolation, purification and mass production. Infected tissues were washed gently with sterile water to remove dirt and contaminants. Tissues were incubated in sterile Petri plates lined with moistened sterile tissue paper for $24 \mathrm{~h}$. In order to obtain pure culture isolate, growing conidia of $C$. citrullina Cooke on infected leaves were aseptically picked with sterile pointed needle under the stereomicroscope and transferred to sterile test tubes previously filled with precooled potato dextrose agar (PDA) culture medium. PDA was prepared by mixing 39 grams of its powder with $1000 \mathrm{ml}$ of distilled water $\left(\mathrm{dH}_{2} \mathrm{O}\right)$ and sterilizing it at $121^{\circ} \mathrm{C}$ for $15 \mathrm{~min}$. Pure cultures of the pathogen were incubated and kept under laboratory conditions.

\section{Preparation of Pathogen's Suspension}

To produce numerous conidia, C. citrullina was re-grown in a specialized culture medium, namely, the bitter gourd-prune medium. The medium was prepared by boiling $200 \mathrm{~g}$ of prune dried fruits in $1000 \mathrm{ml}$ $\mathrm{dH}_{2} \mathrm{O}$ for $30 \mathrm{~min}$. After boiling, $10 \mathrm{ml}$ of prune suspension was transferred to a 250 -ml capacity Erlenmeyer flask previously filled with $100 \mathrm{~g}$ fresh cut 
stems ( 1 inch length) of bitter gourd. The specialized medium was then sterilized at $121^{\circ} \mathrm{C}$ for $15 \mathrm{~min}$. After cooling, part of mycelial growth of C. citrullina in a PDA slant was aseptically transferred into sterilized medium using a sterile flat-end needle. The specialized medium with mycelia of the pathogen was incubated for 7 days under laboratory conditions.

To obtain pure suspension, 7-day old growing mycelia of the pathogen (with conidia) inside specialized medium were then added with $100 \mathrm{ml}$ of sterile $\mathrm{dH}_{2} \mathrm{O}$ and carefully scraped with sterile wire loop to facilitate harvest of the conidia. The suspension was collected by passing it in a double-layered cheesecloth. Finally, suspension of the pathogen was standardized at $1 \times 10^{6}$ conidia $\mathrm{ml}^{-1}$.

\section{Pathogenicity Test}

To check the pathogenicity of isolated $C$. citrullina Cooke, two-week old seedlings of bitter gourd were sprayed with suspension of the pathogen $\left(1 \times 10^{6}\right.$ conidia $\left.\mathrm{ml}^{-1}\right)$ using a hand sprayer. Inoculated plants were immediately covered with clean transparent cellophane plastics (16 x 24 inches) for $24 \mathrm{~h}$ to enhance disease development. After incubation, plastics were removed and plants were kept for 7 to 14 days under screenhouse conditions. Developing symptoms on inoculated leaves were observed and recorded daily.

\section{Laboratory Test}

Four fungicides, namely, benomyl $\left(0.63 \mathrm{~g}\right.$ a.i. $\left.\mathrm{L}^{-1}\right)$, chlorothalonil $(1.41 \mathrm{~g}$ a.i. $\left.\mathrm{L}^{-1}\right)$, copper oxychloride $\left(0.63 \mathrm{~g}\right.$ a.i. $\left.\mathrm{L}^{-1}\right)$ and mancozeb $\left(3 \mathrm{~g}\right.$ a.i. $\left.\mathrm{L}^{-1}\right)$ were used in this study. The stock solution of each fungicide was based on the recommendations found in each bottle/pack. Using a sterile micropipette, $0.5 \mathrm{ml}$ of each fungicide's stock solution and one-half milliliter $(0.5 \mathrm{ml})$ of the pathogen suspension were transferred and mixed in a depression slide. Mixed solutions in slides were then incubated under laboratory conditions. In addition, a mixture of the same amount between sterile $\mathrm{dH}_{2} \mathrm{O}$ and pathogen suspension was also added as control treatment. After $78 \mathrm{~h}$ incubation, growth and development of the conidia of the pathogen were observed daily under the microscope. To determine the efficacy of each fungicide, percentage germinating conidia was calculated by dividing the number of conidia that germinated over the total number of conidia present in each depression slide (based on initial count). 


\section{Screenhouse Test}

Standardized suspension of the pathogen was sprayed on leaves of two-week old seedlings of bitter gourd using a hand sprayer. Inoculated plants were immediately covered with clean transparent cellophane plastics (16 x 24 inches) for $24 \mathrm{~h}$ to enhance disease development. After incubation, plastics were removed and plants were kept for 14 days under screenhouse conditions. When visible symptoms were observed, each previously prepared solution of four fungicides was sprayed onto the leaves of bitter gourd. Separate numbers of seedlings were also sprayed with sterile $\mathrm{dH}_{2} \mathrm{O}$ to serve as control treatment. Care and maintenance of bitter gourd seedlings were employed when necessary. The following data were gathered: a) number of lesions - actual count of lesions taken from the first 3 leaves of the plant before and after fungicide application; b) size of lesions - taken from the first 3 leaves and were measured using a transparent plastic with grids $\left(1 \mathrm{~mm}^{2}\right.$ grid $\left.^{-1}\right)$, and c) disease severity visual estimates of diseased leaves taken from the first 3 leaves of the plant (from the base) before and after fungicide application. Visual estimates were based on a rating scale (1- no infection, 3-1-24\% infection, 5- 25$49 \%$ infection, $7-51-74 \%$ infection and 9- > 75\%).

\section{Experimental Design and Analysis}

Laboratory and screenhouse experiments that had five and six replications, respectively, were both arranged in a completely randomized design. In screenhouse experiment, one plant per pot served as one replicate. All the data were subjected to ANOVA using the $\mathrm{R}$ program (http://cran.r-project.org). Treatment means, on the other hand, were compared through Tukey's test at $5 \%$ level of significance.

\section{RESULTS AND DISCUSSION}

\section{Pathogenicity Test}

Leaf spot disease of bitter gourd started as small, white pin-sized lesions five to seven days after inoculation (Figure 1). As the lesions developed, the size increased and the color changed from white to gray at the center with dark brown margins. Enlarging lesions coalesced with each other causing the whole infected leaves to turn yellow and die. 


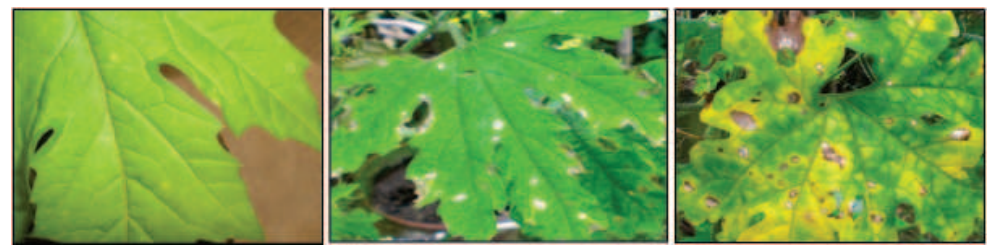

Figure 1. Symptomatology of leaf spot disease of bitter gourd caused by Cercospora citrullina Cooke.

Cercospora generally cause leaf spots not only in bitter gourd but in many plants as well (Chupp, 1953; Tangonan, 1999; Begum, 2012). The fungus usually produces long, slender, colorless, straight to slightly curved, multicellular conidia on short conidiophores which usually arise from the plant surface in clusters through the stomata and form conidia successively on new growing tips (Agrios, 2005). Leaf spot symptoms in many plants caused by Cercospora infection are highly attributed to their toxin called cercosporin. When the toxin is secreted and activated by light, it becomes toxic to its host by generating singlet oxygen (Dickinson, 2003; Daub and Chung, 2007). The singlet oxygen then causes lipid peroxidation in plant membranes and leakage of nutrients, thereby killing the plant's cells and at the same time enhances the virulence of the pathogen. Cercospora species, on the other hand, are not affected by the toxin they release because their spores and mycelia have the ability to produce pyridoxine (vitamin B6) that reacts with the single oxygen atoms and neutralizes the reaction (Agrios, 2005; Daub and Ehrenshaft, 2007).

\section{Laboratory and Screenhouse Tests}

Under laboratory condition, all conidia of C. citrullina did not germinate when treated with different fungicides except in the control (Table 1). All conidia of the pathogen in fungicide treated slides were disintegrated. In untreated control, the conidia of the pathogen remained intact and continued to grow after $72 \mathrm{~h}$. Under screenhouse condition, all test fungicides were also effective in suppressing disease resulting to low number and non-increasing of lesion in the leaves of bitter gourd (Table 2 and Table 3). Visual estimates using a rating scale also revealed that test fungicides suppressed the development of leaf spot disease of bitter gourd caused by C. citrullina (Table 4). In the study of Emua and Fajola (1983), they found that mancozeb together with other fungicides (captan, captafol and phaltan) was effective in inhibiting the conidial germination of Cercospora contraria H. \& P. Syd and Didymosphaeria dinacina (Niessl.) 
Sacc. causing leaf spot diseases of yam (Dioscorea dumetorum) under laboratory and greenhouse experiments. Culbreath et al. (2002), on the other hand, reported that tank mix combinations of half rates of benomyl and chlorothalonil, and alternations of the full rates of the two fungicides provided better control against leaf spot of peanut (Arachis hypogea L.) caused by Cercospora arachidicola S. Hori (teleomorph Mycosphaerella arachidis Deighton) and Cercosporidium personatum (Berk. \& M. A. Curtis) Deighton (teleomorph Mycosphaerella berkeleyi Jenk.) than the full-season applications of either rate of benomyl alone.

Table 1. Conidial germination of Cercospora citrullina at 24, 48 and 72 hours after treatment.

Treatments Conidial germination (\%)

$24 \mathrm{~h} \quad 48 \mathrm{~h} \quad 72 \mathrm{~h}$

Water alone (control)

$62.11 \mathrm{~b}$

89.94 b

$92.57 \mathrm{~b}$

Benomyl

0 a

0 a

0 a

Chlorothanlonil

0 a

$0 \mathrm{a}$

0 a

Copper oxylchloride

0 a

0 a

0 a

Mancozeb

0 a

$0 \mathrm{a}$

$0 \mathrm{a}$

$C V(\%)$

Means with the same letter are not significantly different at 5\% level of significance using Tukey's Test.

Aside from Cercospora, benomyl, chlorothalonil, copper oxychloride and mancozeb have been also proven effective against other groups of important fungal plant pathogens (Enyinnia, 1996; Bushong and Timmer, 2000; Peres et al. 2002; Mueller et al., 2002; Chatage and Bhale, 2011; Syed et al., 2012). Benomyl is a systemic, broad spectrum fungicide that belongs to the chemical group of benzimidazole which specializes in disrupting the $\beta$-tubulin assembly in mitosis as well as DNA and RNA synthesis (Vyas, 1984; FRAC, 2010). Chlorothalonil, copper oxychloride and mancozeb, likewise, are broad-spectrum but contact fungicides that belong to chloronitrile, inorganic and dithiocarbamate chemical groups, respectively (Thomson, 1993). These fungicides are known for their multisite activities inside fungal biochemical systems. The mode of action of 
chlorothalonil starts with its reaction with glutathione, coenzyme-A, 2mercaptoethanol and other compounds forming several S-derivatives. By this the SH-content in cells is significantly reduced which results in lethal inhibition of a number of thiol dependent reactions (enzymes) in fungal cells (Gastonyi and Lyr, 1987; Yang et al., 2011). The direct effect of mancozeb unto the core biochemical processes of the target fungus, on the other hand, is the inhibition of spore germination (Gullino et al., 2010). Furthermore, these fungicides are highly recognized for low risk in terms of development of resistance by any fungus as compared to benomyl and other systemic fungicides (FRAC, 2010; Gullino et al., 2010; Yang et al., 2011). Aside from being preventive, these fungicides actually have curative effects, too, to disease causing pathogens of crops (Thompson, 1993). However, their efficacies are limited due to their contact characteristics. That is, their toxicity will only take effect for those vulnerable structures of the pathogens that will be hit or contacted during spray applications.

Table 2. Number of lesions in leaves of bitter gourd at $0,2,4,6,8$ and 10 days after treatment.

\begin{tabular}{lllllll}
\hline Treatments & \multicolumn{5}{c}{ Number of lesions leaf } \\
\cline { 2 - 7 } & \multicolumn{7}{c}{${ }^{1}$} \\
Water alone (control) & $4.83 \mathrm{a}$ & $7.11 \mathrm{~b}$ & $8.01 \mathrm{c}$ & $9.67 \mathrm{c}$ & $9.67 \mathrm{c}$ & $9.60 \mathrm{c}$ \\
Benomyl & $4.61 \mathrm{a}$ & $5.00 \mathrm{a}$ & $5.00 \mathrm{a}$ & $5.12 \mathrm{a}$ & $5.12 \mathrm{ab}$ & $5.12 \mathrm{a}$ \\
Chlorothalonil & $4.22 \mathrm{a}$ & $5.12 \mathrm{a}$ & $6.12 \mathrm{~b}$ & $6.12 \mathrm{ab}$ & $6.50 \mathrm{~b}$ & $6.67 \mathrm{~b}$ \\
Copper oxychloride & $4.33 \mathrm{a}$ & $4.40 \mathrm{a}$ & $4.50 \mathrm{a}$ & $4.50 \mathrm{a}$ & $5.00 \mathrm{ab}$ & $5.43 \mathrm{ab}$ \\
Mancozeb & $5.00 \mathrm{a}$ & $5.11 \mathrm{a}$ & $5.13 \mathrm{a}$ & $5.14 \mathrm{ab}$ & $5.18 \mathrm{a}$ & $5.17 \mathrm{ab}$ \\
CV (\%) & 17.88 & 13.73 & 9.01 & 13.77 & 13.75 & 13.91 \\
\hline
\end{tabular}

Means with the same letter are not significantly different at 5\% level of significance using Tukey's Test.

Controlling diseases in plants caused by fungi can be done in any of the following methods: use of resistant varieties, cultural control, physical control, biological control and chemical control. Among the methods, chemical control through application of fungicide is the most commonly used method especially if the incidence and severity of the disease in a certain crop is beyond the allowable level of infection and at the same time other control methods fail to accomplish the task of suppressing or 
Sensitivity of leaf spot causing pathogen of bitter gourd to different fungicides

Table 3. Lesion size development in leaves of bitter gourd at $0,2,4,6,8$ and 10 days after treatment.

\begin{tabular}{|c|c|c|c|c|c|c|}
\hline \multirow[t]{2}{*}{ Treatments } & \multicolumn{6}{|c|}{ Size of lesions leaf ${ }^{-1}\left(\mathrm{~mm}^{2}\right)$} \\
\hline & $0^{1}$ & 2 & 4 & 6 & 8 & 10 \\
\hline Water alone (control) & $1.56 \mathrm{a}$ & $20.29 \mathrm{~b}$ & $40.89 \mathrm{~b}$ & $120.00 \mathrm{~b}$ & $189.00 \mathrm{~b}$ & $214.11 b$ \\
\hline Benomyl & $1.53 \mathrm{a}$ & $2.00 \mathrm{a}$ & $2.00 \mathrm{a}$ & $2.50 \mathrm{a}$ & $2.50 \mathrm{a}$ & $2.50 \mathrm{a}$ \\
\hline Chlorothalonil & $1.83 \mathrm{a}$ & $2.00 \mathrm{a}$ & $2.50 \mathrm{a}$ & $3.00 \mathrm{a}$ & $4.00 \mathrm{a}$ & $4.50 \mathrm{a}$ \\
\hline Copper oxychloride & $1.67 \mathrm{a}$ & $2.00 \mathrm{a}$ & $2.00 \mathrm{a}$ & $2.00 \mathrm{a}$ & $2.50 \mathrm{a}$ & $2.50 \mathrm{a}$ \\
\hline Mancozeb & $1.83 \mathrm{a}$ & $2.00 \mathrm{a}$ & $2.00 \mathrm{a}$ & $3.00 \mathrm{a}$ & $3.00 \mathrm{a}$ & $3.00 \mathrm{a}$ \\
\hline$C V(\%)$ & 16.14 & 19.72 & 20.08 & 21.67 & 16.76 & 16.24 \\
\hline
\end{tabular}

Means with the same letter are not significantly different at 5\% level of significance using Tukey's Test.

Table 4. Severity of leaf spot disease in bitter gourd caused by Cercospora citrullina at 0, 2, 4, 6, 8 and 10 days after treatment. ${ }^{1}$

\begin{tabular}{lcccccc}
\hline Treatments & \multicolumn{5}{c}{ Size of lesions leaf ${ }^{1}\left(\mathrm{~mm}^{2}\right)$} \\
\cline { 2 - 7 } & $0^{2}$ & 2 & 4 & 6 & 8 & 10 \\
\cline { 2 - 7 } Water alone (control) & $2.33 \mathrm{~b}$ & $3.00 \mathrm{c}$ & $3.83 \mathrm{c}$ & $5.00 \mathrm{c}$ & $5.67 \mathrm{c}$ & $5.83 \mathrm{c}$ \\
Benomyl & $2.00 \mathrm{a}$ & $2.00 \mathrm{a}$ & $2.00 \mathrm{a}$ & $2.00 \mathrm{a}$ & $2.00 \mathrm{a}$ & $2.00 \mathrm{a}$ \\
Chlorothalonil & $2.67 \mathrm{bc}$ & $2.67 \mathrm{bc}$ & $2.67 \mathrm{~b}$ & $2.67 \mathrm{~b}$ & $2.67 \mathrm{~b}$ & $2.67 \mathrm{~b}$ \\
Copper oxychloride & $3.00 \mathrm{c}$ & $3.00 \mathrm{c}$ & $3.00 \mathrm{~b}$ & $3.00 \mathrm{~b}$ & $3.00 \mathrm{~b}$ & $3.00 \mathrm{~b}$ \\
Mancozeb & $3.00 \mathrm{c}$ & $3.00 \mathrm{c}$ & $3.00 \mathrm{~b}$ & $3.00 \mathrm{~b}$ & $3.00 \mathrm{~b}$ & $3.00 \mathrm{~b}$ \\
CV (\%) & 31.08 & 23.52 & 33.67 & 28.78 & 30.61 & 26.99 \\
\hline
\end{tabular}

1- Visual estimates based on rating scale (1- no infection, 3- 1-24\% infection, 5- 25-49\% infection, 7-51-74\% infection and 9->75\%).

2-Means with the same letter are not significantly different at 5\% level of significance using Tukey's Test. 
reducing severe infections. It should be kept in mind that chemical control through fungicide should not be solely used as control as this will contaminate the environment, cause unhealthy effects to humans and other animals, and may cause development of resistance by fungi.

\section{CONCLUSION}

C. citrullina Cooke causing leaf spot disease of bitter gourd was very sensitive to benomyl, chlorothalonil, copper oxychloride and mancozeb. All the four fungicides were very effective against the causal pathogen even if the infection had already occurred. Hence, these fungicides can be used to cure high incidence and severe infection of the pathogen causing leaf spot in bitter gourd. Which one should be used, on the other hand, is a matter of choice based on the price and availability in the market.

\section{REFERENCES}

ANONYMOUS. 2009. Cercospora leaf spot of bitter gourd. http://www.eastwestseed.com/guide_tips/disease.html. December 11, 2009.

AGRIOS, G.N. 2005. Plant Pathology. $5^{\text {th }}$ Ed. Elsevier Academic Press. Burlington, MA, USA. $916 \mathrm{p}$.

BAS. 2008. Bureau of Agricultural Statistics. http://countrystat.bas.gov. $\mathrm{ph} / \mathrm{selection}$.asp. November 26, 2008.

BEGUM, M.M, T.U. DALISAY and C.J.R CUMAGUN. 2012. Taxonomic review and development of a lucid key for Philippine Cercosporoids and related fungi. http://www.intechopen.com/books/plantpathology/development-of-a-lucid-key-for-philippine-cercosporoids andrelated-fungi

BUSHONG, P.M. and L.W. TIMMER. 2000. Evaluation of postinfection control of citrus scab and melanose with benomyl, fenbuconazole, and azoxystrobin. Plant Dis. 84 (11): 1246-1249.

CHATAGE, V.S. and U.N. BHALE. 2011. Efficacy of fungicides against Alternaria pluriseptata and Geotrichum candidus incitant of ivy gourd fruit. Int. J Latest Trends Bot. Sci. 1 (1): 1-4.

CHUPP, C. 1953. A Monograph of the Fungus Genus Cercospora. Ithaca, New York. 667p. 
Sensitivity of leaf spot causing pathogen of bitter gourd to different fungicides

CULBREATH, A.K., K.L. STEVENSON and T.B. BRENNEMAN. 2002. Management of late leaf spot of peanut with benomyl and chlorothalonil: A study in preserving fungicide utility. Plant Dis. 86:349-355.

DAUB, M.E. and K.R. CHUNG. 2007. Cercosporin: A phytoactivated toxin in plant disease. http://www.apsnet.org/publications/ apsnetfeatures/ Pages/Cercosporin.aspx

DAUB, M.E. and M. EHRENSHAFT. 2000. The photoactivated cercospora toxin cercosporin: contributions to plant disease and fundamental biology. Annu Rev Phytopathol. 38: 461-490.

DICKINSON, M. 2003. Molecular Plant Pathology. Bios Scientific Publishers. London and New York. 273 p.

EMUA, S.A. and A.O. FAJOLA. 1983. Chemical control of two leaf spot diseases of cluster yam (Dioscorea dumetorum) caused by Cercospora contraria and Didymosphaeria donacina. Plant Dis. 67:389-391.

ENYINNIA, T. 1996. Effect of two systemic fungicides on rice blast control in a rainforest zone of Nigeria. Inte. J. Pest Manage. 42(2): 77-80.

FRAC. 2010. FRAC Code List: Fungicides sorted by mode of action. Fungicide Resistance Action Committee. $10 \mathrm{p}$.

GASTONI, M. and H. LYR. 1987. Other fungicides. In: Modern Selective Fungicides: Properties, Applications and Mechanisms of Actions. H. Lyr (Ed.). Longman Scientific and Technical, and John Wiley and Sons, Inc., New York. pp. 309-324.

GULLINO, M.L., F. TINIVELLA, A. GARIBALDI, G.M. KEMMIT, L.BACCI and B. SHEPPARD. 2010. Mancozeb: past, present and future. Plant Dis. 94(9): 1076-1087.

MALOY, O.C. 1993. Plant Disease Control: Principles and Practices. John Wiley and Sons Inc., New York, USA. 346 p.

MUELLER, D.S., A.E. DORRANCE, R.C. DERKSEN, E. OZKAN, J.E. KURLE, C.R. GRAU, J.M. GASKA, G.L. HARTMAN, C.A. BRADLEY and W.L. PEDERSEN. 2002. Efficacy of fungicides on Sclerotinia sclerotiorum and their potential for control of sclerotinia stem rot on soybean. Plant Dis.86(1): 26-31. 
NENE, Y.L. and P.N. THAPLIYAL. 1993. Fungicides in Plant Disease Control $\left(3^{\text {rd }}\right.$ Ed.) International Science Publisher, New York. 691 p.

PERES, N.A.R., N.L. SOUZA and L.W. TIMMER. 2002. Activity of benomyl for control of postbloom fruit drop of citrus caused by Colletotrichum acutatum. Plant Dis. 86(6): 620-624.

PHILRICE. 2007. Training Guide for Palayamanan Vegetable Production. Philippine Rice Research Institute, Maligaya, Science City of Muñoz, Nueva Ecija. 146 p.

TANGONAN, N.G. 1999. Host Index of Plant Diseases in the Philippines. $\left(3^{\text {rd }}\right.$ ed.). Philippine Rice Research Institute, Maligaya, Science City of Muñoz, Nueva Ecija. 468p.

THOMSON, W.T. 1993. Agricultural Chemicals: Book IV-Fungicides. Thomson Pub., USA. 226 p.

SYED, D.Y., T. MENGESTEAB, N. ROBIEL, W. ROBIEL and Z. TEKLE. 2012. Efficacy of garlic extract and mancozeb against seed borne fungal pathogen of farmer saved sorghum (Sorghum bicolor) and groundnut (Arachis hypogaea) seeds. Greener Journal of Agricultural Sciences 2 (2):31-36.

VYAS, S.C. 1984. Systemic Fungicides. Tata McGraw-Hill Pub. Co. Limited, New Delhi, India. 360 p.

YANG, C., C. HAMEL, V. VUJANOVIC and Y. GAN. 2011. Fungicide: modes of action and possible impact on nontarget microorganisms. ISRN Ecology 2011. http://dx.doi.org/10.5402/2011/130289

ZAMORA, F.N.JR. 1993. Cultivating ampalaya as a cure for diabetes. Agriscope 7(2):18-19. 